\title{
NGO legitimacy
}

DOI:

10.1080/00344893.2015.1023102

\section{Document Version}

Final published version

Link to publication record in Manchester Research Explorer

\section{Citation for published version (APA):}

Thrandardottir, E. (2015). NGO legitimacy: four models. Representation, 51(1), 107-123.

https://doi.org/10.1080/00344893.2015.1023102

\section{Published in:}

Representation

\section{Citing this paper}

Please note that where the full-text provided on Manchester Research Explorer is the Author Accepted Manuscript or Proof version this may differ from the final Published version. If citing, it is advised that you check and use the publisher's definitive version.

\section{General rights}

Copyright and moral rights for the publications made accessible in the Research Explorer are retained by the authors and/or other copyright owners and it is a condition of accessing publications that users recognise and abide by the legal requirements associated with these rights.

\section{Takedown policy}

If you believe that this document breaches copyright please refer to the University of Manchester's Takedown Procedures [http://man.ac.uk/04Y6Bo] or contact uml.scholarlycommunications@manchester.ac.uk providing relevant details, so we can investigate your claim.

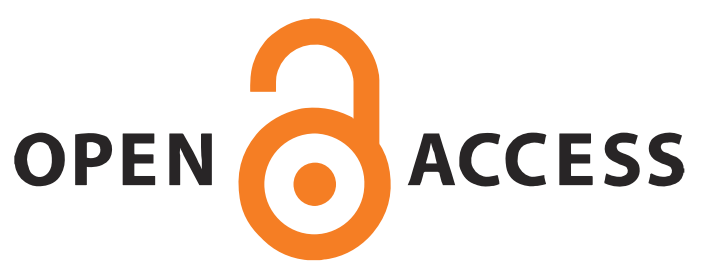




\section{NGO LEGITIMACY: FOUR MODELS}

\section{Erla Thrandardottir}

To cite this article: Erla Thrandardottir (2015) NGO LEGITIMACY: FOUR MODELS, Representation, 51:1, 107-123, DOI: 10.1080/00344893.2015.1023102

To link to this article: https://doi.org/10.1080/00344893.2015.1023102

Published online: 19 Mar 2015.

Submit your article to this journal

III Article views: 1737

View Crossmark data \lceil

47 Citing articles: 8 View citing articles 진 


\title{
NGO LEGITIMACY: FOUR MODELS
}

\author{
Erla Thrandardottir
}

This paper examines the legitimacy of NGOs in the context of international politics. Legitimacy is increasingly associated with NGOs in the role of political actors on a global stage. However, conceptualisation of NGO legitimacy is unclear in the literature. The paper proposes four legitimacy models to clarify how their legitimacy is theorised: the market model, the social change model, the new institutionalism model, and the critical model. The paper's argument is that the models represent four different schools of thought on NGO legitimacy each with a different understanding of NGOs' role in the international system. Each model is discussed based on the theoretical premises they adapt, the legitimacy criteria and the arguments this generates, and the conclusions they make about the legitimate role of NGOs at the international level. The models provide a heuristic starting point for exploring how $N G O s$ can be theorised as legitimate (rightful and credible) actors in international structures.

You may love them or loathe them, but are they legitimate? Governments, intergovernmental bureaucrats, and global corporations are all well aware of the impact NGOs can have on their affairs. Their heightened attention to NGOs' impact on global affairs poses challenging questions about NGOs' legitimacy. Who invited NGOs to the global party? Whom or what do they represent? And in what context are we to understand their legitimacy? The mechanisms normally applied to determine the legitimacy of actors in the public and private sectors (i.e., elections and principal-agent contracts) do not seem to apply to NGOs. Likewise, NGOs are not trying to be elected representatives; nor are they seeking profits from their work. So what are NGOs doing that requires legitimation? What is it that defines NGOs as actors that need legitimacy?

In seeking to shed some light on these questions, I propose four models to frame the discussion in the literature on the issue of NGO legitimacy. These are the market model, the social change model, the new institutional model, and the critical model. The models are proposed as heuristic frameworks to explore how NGO legitimacy is theorised in the literature and how this affects the evaluation of their legitimate role in global politics. The literature I draw on is NGO specific and selected based on its relevance to the discussion at hand, that is, how NGOs can be included as legitimate actors in global forums with something to offer that is different from states and corporations.

Exploring the legitimacy of NGOs as global actors is a direct challenge to conceptions of state sovereignty and the prevailing explanations of who can make new rules and preside over them in the international system (Clark 2007a). The emergent transnational public spheres of globalisation have created new publics and expanded the political audiences (Crack 2013). These new publics introduce different categories of constituents that trivialise sovereignty and challenge states as the only legitimate actors in global politics. This has introduced competing conceptions of legitimacy, some of which suggest that new global actors can 'act as a 
solvent against the strictures of sovereignty' (Charnovitz 2006: 348). Some scholars argue that NGOs can restore institutional chains of communication in polities where the public has become democratically disengaged (Lang 2012). However, failure of NGOs to deliver on their promises, local politics, and differing normative priorities has caused others to focus on the constituents of NGOs and whose voices, interests, and values are being represented (Halpin and McLaverty 2010; Jeater 2011; Walton 2013).

Whether NGOs are theorised as representatives of universal values or global publics, their rise to prominence is echoed at all levels of governance (Committee of Ministers 2007; Short 1999; United Nations 2004). This puts pressure on NGOs to explain and defend their legitimacy: 'How long can NGOs afford to turn a blind eye to the nagging demand that they improve their legitimacy while at the same time run the increasing risk that states will take the initiative to impose their own criteria on them?' (Kamminga 2007: 195). The variety of approaches to NGO legitimacy raises a question about how to prioritise the criteria of evaluation. Should NGO legitimacy be measured according to democratic values, moral arguments, or contractual obligations? Another specific problem is the shortcoming between domestic and international legitimacy, which revolves around NGOs' difficulty in establishing legal validity at the international level (Charnovitz 2006: 356; Kissling 2008). This has created a problem for the theorisation of NGO legitimacy because it highlights the interconnectedness of legality and legitimacy and in so doing raises difficult questions about how to understand NGO legitimacy at the international level.

Before discussing the models, a short note is offered on the term NGO and the concept of legitimacy and how they are used in this paper.

There are many definitions of NGOs in the literature. These definitions use a varied vocabulary to describe their unit of analysis-for example, civil society organisations, non-profits, etc.--sometimes reflecting the theoretical propositions implied about NGOs' purpose and role (Götz 2008; Jordan and Tuijl 2006; Vakil 1997). However, there are common features that constitute a unit of analysis and justify using a single term, NGO, to cover all these varieties. Two commonly referenced definitions are Salamon and Anheier's structural definition, rooted in a domestic context, and the UN ECOSOC definition, rooted in an international context (Salamon and Anheier 1997: 33-4; Willetts 2011: 6-8). Based on these, the term NGO is used in this paper to refer to: (a) organisations whose purpose is for the public good, but not governmental or profitable in nature and (b) that these organisations fulfil the minimum legal requirements of the regulatory regimes they comply with. The models reflect different terminologies and this is listed in Table 1 (located towards the end of the paper), but the term NGO is used throughout to provide consistency.

Legitimacy is a complex concept and applying it to NGOs is not a straightforward exercise. At its most basic level legitimacy indicates two things, (a) that an entity is lawful and (b) that an entity is credible. This can sometimes cause confusion as an entity's credibility does not always go with it being lawful and vice versa. Nuances in these meanings are highlighted by the models. The organisation of the literature has been informed by Beetham's theory on legitimation of power, which encompasses both normative and social aspects of the concept. By emphasising a broad understanding of legitimacy, the paper teases out different dimensions of legitimacy, including both reasons for legitimacy and perceptions of legitimacy, thus reflecting the dual meaning of the concept (Beetham 1991 [2013]). The purpose of applying a broad understanding of legitimacy is to reflect the wide range of legitimacy criteria presented in the models, such as legality, representation, and accountability. What I wish to stress here is that the models offer a spectrum of theories that highlight this dual meaning and a range of 
legitimacy criteria. The ultimate aim of applying legitimacy to NGOs is to look for answers on whether, and how, they can be included as legitimate actors in global politics.

The models are a way to organise the literature and facilitate a comparison between different approaches, and thus provide a spectrum of legitimate NGO roles. The models are used as frameworks to explore theories and arguments that can help advance our understanding of NGO legitimacy. For example, is NGO legitimacy constituted (social change model), or conferred (new international model), regarded as a function of markets (market model), or about political empowerment (critical model)? The purpose of the paper is to highlight four distinct understandings of NGO legitimacy that can explain NGOs' role in global politics. These are about (a) the efficiency NGOs bring to the spending of public funds as deliverers of welfare services; (b) NGOs as an associational form that enables democracy and thus improves the quality of society; (c) NGOs' ability to bring about normative change in international institutions; and (d) NGOs facilitating representation of marginalised people (or causes) in the international system. Each model also evaluates NGOs' legitimate role as being apolitical, semi-political, or political.

The models will be discussed in the following order, the market model, the social change model, the new institutional model, and the critical model. The paper concludes with a brief discussion to tease out the main points from each model. Table 1 provides a comprehensive overview of the models.

\section{The Market Model}

The market model provides a framework for analysing the role of NGOs in the context of market economies. NGOs are theorised as private actors that can offer alternative ways to deliver governmental services and policies, whether domestic or international. The shared features of the market model are characterised by supply and demand analysis, accountability measures, and legitimacy understood as credibility in the context of market economies.

The role of NGOs is viewed as auxiliary to, and under the tutelage of, states. The overall focus is on analysing how NGOs function in the context of market economies with emphasis on their utility and shared goals. Arguments presented in market model theories claim that NGOs either have a comparative advantage over, or a complementary function to states and IGOs for delivering programmes and policies (Gidron et al. 1992: 5-8; Weisbrod 1998). This (market economy) contextualisation of NGO legitimacy entails focusing on NGOs' ability to deliver welfare services and policies, often through contractual arrangements. Because the emphasis is on analysing the functional utility of NGOs, the market model does not challenge state sovereignty; rather it reinforces it. Subsequently, NGOs' legitimate role is theorised as apolitical.

There are two things to highlight: the functional emphasis on NGOs' role, and the accountability emphasis on their legitimacy.

Frumkin's functional theory provides a good insight into a supply and demand analysis of NGOs. Frumkin makes a distinction between NGOs having a role as either public organisations (demand-side) or private organisations (supply-side) (Frumkin 2002: 177). On the one hand is the demand-side, which focuses on public utility and NGOs' ability to meet the needs of their beneficiaries '[in an area] where the market and the state cannot or will not go' (Frumkin 2002: 176). On the other hand is the supply-side, which focuses on the people working in, or alongside, the sector (such as donors and social entrepreneurs) and how they drive the sector forward. Frumkin argues that NGOs need to keep the demand and supply sides in balance to avoid antagonising supporters by appearing either too commercial, too 
political, or too particularistic (Frumkin 2002: 27). Frumkin's theory highlights the usefulness of contextualising NGOs in markets because it offers an analysis of the limits of the voluntary sector vis-à-vis the state. It also underscores that the line between non-profit organisations and for-profit businesses can be thin (Phills 2005).

However, Frumkin's theory does not (nor is it intended to) address the role of NGOs at the international level. Globalisation and growing visibility of NGOs as global actors raise new challenges for analysing their legitimacy. Holding NGOs to account for their actions globally brings to the fore a particular challenge on how we are to understand NGO legitimacy at the international level; namely what is their global constituency and to whom are NGOs accountable (Charnovitz 2006). Answering these questions is problematic since what counts as 'a public' at the international level is highly contested (Eriksen and Sending 2013; Lang 2012).

Brown (2008) confronts the accountability dilemma by suggesting a framework for managing the credibility of NGOs through peer review. According to Brown, NGO legitimacy should rest on how NGOs manage their credibility as a sector at the international level. Brown's credibility theory proposes a self-regulatory mechanism in the form of peer review, as opposed to elections and principal-agent formats, which enables NGOs to manage their legitimacy as a sector (Brown 2008).

One result of Brown's credibility theory is the International NGO Accountability Charter and its regulatory supplement, the Global Reporting Initiative (INGO Accountability Charter 2005; INGO Accountability Charter 2014: 3). Whilst the Charter is a pledge, the reporting scheme is a two hundred pages long document that outlines how to measure NGOs' accountability in terms of values proposition, governance, and programme effectiveness (Global Reporting Initiative 2011: 7). Both centre on NGO accountability as a response to legitimacy problems set forth by donors (or those in power). The target audience for the regulatory supplement are listed to be: ' . . organizations researching the accountability of NGOs, decisionmakers from the government and corporate sectors, other NGOs, existing and potential donors, partners, and affected stakeholders' (Global Reporting Initiative 2011: 6). Likewise, the Charter lists many powerful entities (states, media, donors) in relation to whom NGOs are accountable to. This indicates that their accountability is a response to expectations from authoritative entities.

Furthermore, NGO legitimacy analysed as credibility is about managing reputation. Criticism that can damage NGOs' reputation as a sector is more likely to come from someone powerful than someone who is powerless. NGOs' effort to set up the Charter and its regulatory supplement is a response to criticism about their legitimacy, from those in power (Kamminga 2007). In meeting the demands of their critics with such elaborate measures, NGOs imply that they are seeking approval in order to legitimise their role at the international level. The danger is that NGOs start to focus on obtaining endorsements from donors to legitimise their power and secure their role, which can desensitise NGOs to the accountability responsibilities they have towards their less powerful stakeholders. (And possibly distort it by letting donors define NGO legitimacy through agenda setting.)

The downside of creating sharp accountability measures is that it biases NGOs' response to deal with criticism from those on the supply side in Frumkin's theory-and in meeting their expectations, reinforce the interests of those in power. Another downside of accountability well defined, is internal to NGOs. As the boundaries of decision-making are pushed towards for-profit understandings, the balance of power tilts in favour of trustees and executive committees at the expense of beneficiaries (Frumkin 2002: 7; Hone 1989). 
The market model may be well suited to analyse NGOs that are not organised around or centred on members, that is, where members play a passive role as donors rather than activists or private foundations involved in philanthropy. The shortcomings of the market model are its failure to deliver analytically on the social, normative, and political dimensions of NGO legitimacy (Ebrahim 2009; Gidron et al. 1992: 28). These aspects are discussed in the other models. The market model legitimises an apolitical and functional role and downplays NGOs' politically ambitious objectives, thus only partially explaining NGO legitimacy.

\section{The Social Change Model}

The social change model highlights the link between legitimacy and democracy. The premise underlying the defining features of the social change model is freedom of association. The role of NGOs is legitimised as a dutiful civic role that is essential to a liberal democratic system and seen as intrinsically good for society. NGO legitimacy thus understood is constitutive and generated internally rather than conferred onto NGOs by external entities. Because of the assumption that NGOs are constitutive actors, many of the theories under to the social change model apply 'bottom-up' approaches to analyse NGOs' distinct role in society (Clemens 2006; Hilton et al. 2010; Putnam 2000).

The social change model emphasises NGOs as independent entities of the third sector. The parameters of the NGO sector were established by Salamon and Anheier's (1997) universal classification system. The system emphasises the size and independence of the sector as a rival force in society. It has generated numerous cross-country studies, undertaken to establish the size of the sector in various countries, and to provide quantitative underpinnings to NGOs as a global force (Anheier and Katz 2004; Kendall and Knapp 1996). In addition to raising the profile of NGOs as new, international, and powerful actors, it has also triggered concerns about their legitimacy.

The social change model raises specific questions about how to understand NGO legitimacy in global forums. The questions revolve around NGOs' representativeness and their constitutiveness. Is the collective voice of NGOs dependent on the active participation of their members, or does the force of their argument suffice? (O'Neill 2001) That is, if NGOs are providing legitimacy to intergovernmental institutions as representatives of 'global public opinion' how should their representativeness be understood? (Slim 2002; United Nations 2004; Willetts 2006) And if NGOs are to be 'agents of democracy' that can 'provide a link between the governed and those doing the governing' to what degree does their interaction with members matter? (Halpin 2009: 70-7, 261)

The issue of representation is problematic for NGOs because, as Brown points out, they are neither states nor for profit thus the existing mechanisms of accountability do not apply (Brown 2008). There are two competing explanations for the representativeness of NGOs, one focuses on whom NGOs represent and the other on what they represent. The essence of the whom argument is that NGOs are representative entities and need to have active participation from their members to claim representation. The essence of the what argument is that NGOs are essentially constitutive entities whose legitimacy relies on socialisation and normative reasons, which shifts the focus on the qualitative aspects of NGOs legitimacy, for example, the reasons NGOs provide to justify their work, that is, the strength of their argument, and how they create space (are harbingers) for socialisation and civil society politics (Steffek and Hahn 2010: 16-20). 
The whom line of argument understands NGO legitimacy as essentially representative entities. Without identifiable constituents, legitimacy can only be measured in indicators of solidarity not democracy. Responding to O'Neill's argument, Halpin and McLaverty state that any discussion on whom NGOs represent requires constituents, which by default excludes the notion of what NGOs represent. Consequently, NGOs' ability to represent can only be understood in democratic terms where there are identifiable constituents (i.e., members). According to Halpin and McLaverty, the what argument can only explain NGO legitimacy in terms of solidarity not representation because there are no identifiable constituents (Halpin and McLaverty 2010: 65-9). Without members and without the opportunity to implement internal democratic processes, NGO legitimacy can only be analysed as solidarity. Any requests to demonstrate representativeness without identifiable members are futile and unreasonable.

The what line of argument understands NGO legitimacy as essentially constitutive. Peruzzotti argues that the question of whom NGOs represent is problematic because it is directly linked with whom they are accountable to. He elaborates that accountability can only be upwards since it is a mechanism to prevent the abuse of power that has been delegated. The only delegation of power to NGOs is from donors, which makes NGOs increasingly preoccupied with justifying their work to donors. Consequently, NGOs lose their perspective as organisations working for the poor and disempowered (who have possibly not delegated any power to them). To improve NGO accountability measures and preserve civil society as an arena for 'creative self-constitution of new actors and voices', NGOs should 'avoid the dangers of a statist approach to the problem' as it endangers the autonomy of the sector, 'for civil society organisations are not representative but constitutive institutions' (Peruzzotti 2006: 55-6). According to Peruzzotti's argument, we need to focus on NGOs' democratic and socialisation abilities, their constitutiveness, when assessing their legitimacy:

If civil society represents a specific form of society that aims at moulding social relationships around the normative principles entailed in modern constitutionalism, the question of how to democratize social beliefs, practices and associational life should become a key priority of democratizing forms of civic engagement. (Peruzzotti 2006: 56)

This entails, Peruzzotti argues, holding NGOs to a higher ethical and legal standards to prevent 'a small group of corporations, the government, political parties, private interest associations, and "the usual suspects"' from capturing the public sphere (Peruzzotti 2006: 56). This brings us back to the politics and the legitimate role of NGOs as global actors.

The social change model is concerned with the democratic role of NGOs in international politics. It focuses on whether NGO legitimacy should be benchmarked against their representativeness or their constitutiveness. The main difference lies in the analytical emphasis of whom or what NGOs represent. The model demonstrates that the internal social and democratic organisation of NGOs matters and that accountability is of a democratic nature rather than about NGOs' efficiency in the marketplace. The questions about 'whom NGOs represent' and 'what NGOs represent' both embrace NGOs as semi-political actors albeit with different premises, one focuses on members the other on principles (Clark 2007a: 23).

In sum, the social change model frames the analyses to elucidate NGOs' democratic agency and constitutive abilities. NGOs legitimacy is constitutive and generated endogenously. The model pushes the envelope on who can be a recognised member of international society by analysing NGO legitimacy as a constitutive and democratic right. The model theorises NGO legitimacy in the context of democracy highlighting the defining features of NGO legitimacy, 
such as representativeness, freedom of individuals to associate, third sector analysis, and the intrinsic value of NGOs to a democratic society.

\section{The New Institutional Model}

Contrary to the social change model that emphasises the autonomy of the third sector and the democratic nature of NGOs, the new institutional model focuses on normative legitimacy and how NGOs are embedded in global structures. According to Mathews, the rising prominence of NGOs as global actors signifies a power shift: 'The steady concentration of power in the hands of states that began in 1648 with the Peace of Westphalia is over' (Mathews 1997: 1). This statement epitomises the legitimacy premise of the new institutional model: power is no longer the privilege of states. The research focus is shifted to NGOs' involvement in decision-making, and a rethinking of how to evaluate their legitimacy (Bodansky 1999: 597).

Theories in the new institutional model are preoccupied with normative accounts of NGO legitimacy that can explain their participation as legitimate actors in a complex institutional system not designed for NGOs. There are two things to highlight about how NGOs are embedded in global structures: (a) theories about NGOs as legitimate participants in their own right (rightful participants) and (b) theories about NGOs as auxiliaries, that is, proxy publics, to institutions (legitimacy gap fillers).

States guard the privileges of their sovereign powers as gold. However, this privilege is increasingly being challenged where many scholars argue that NGOs are powerful actors who can rightfully expect to be recognised as members of international structures alongside states and other non-state actors (Bexell 2014; Keck and Sikkink 1999; Pattberg 2005).

Discussions on NGO legitimacy often trivialise the concept of sovereignty to make inroads for non-state actors. These arguments raise doubts as to whether states can continue to claim to be the only lawful actor in international politics and raise challenging questions about membership and the future direction of the international system (Clark 2007b; Scholte 2007). For example, Buchanan and Keohane argue that we need a new global standard to measure legitimacy at the international level because state consent does not account adequately for global power (Buchanan and Keohane 2006: 414-15). NGOs are essential for this scheme to work because they provide a check on the decision-making of global institutions, which 'helps to compensate for the limitations of accountability through democratic state consent' (Buchanan and Keohane 2006: 432-36). Charnovitz goes further and argues that excluding NGOs from participating fully in global governance is illegitimate and that other actors (i.e., states) 'have a duty to provide opportunities for NGOs'. He goes on to say that the role of NGOs at the international level is to 'correct for the pathologies of governments and IOs' (Charnovitz 2011: 894-95). Thus, NGOs are rightful participants, and necessary to counter the power of states.

The crux in many of the arguments is that NGOs' normative entrepreneurialism makes them ideal candidates for delivering soft power. In the context of global governance, the input of NGOs is often analysed in terms of their expertise. That is, NGOs' expertise contributes to norm creation in global institutions where they take something that is perceived 'as natural or appropriate and convert it into something perceived as wrong or inappropriate' thus prompting a changed behaviour in other actors (Finnemore and Sikkink 1998: 899-900). Clarks' detailed analysis of how Amnesty International has reinforced human rights norms in international law shows how influential a single NGO can be (Clark 2001). 
Some scholars argue that one way to overcome the legitimacy issue of NGOs is to make private self-regulatory regimes compatible with global structures and thereby provide a muchneeded democratic control of their actions. This entails the prospect of embedding self-regulatory regimes as parallel structures in global governance to confer legitimacy onto NGOs (Bernstein 2011; Maragia 2002). The focus is on inclusion of NGOs, whether with emphasis on parallel self-regulation or incorporation into international institutional law (Cashore 2002; Macdonald 2008; Reimann 2006). In this, the new institutional model shares with the market model a view of NGOs as complementary actors in a supportive role to governmental bodies, albeit driven by norms.

The corollary of this analysis is that NGOs' embedding in international structures is sometimes regarded as a legitimacy boost for intergovernmental institutions. Lang argues that NGOs have obtained a seat at the political table, not as 'catalysts of public voice' but as 'proxy publics', where NGOs have replaced citizen participation as 'incubators of publics' (Lang 2012: 26-32). In order to justify their own decision-making processes and policy outcomes as more democratic, intergovernmental institutions provide NGOs with a platform to participate in global governance. The argument is that NGOs' input and seat at the table as representatives of 'global civil society' (Wapner 1996) representing 'global public opinion' (United Nations General Assembly 2004) provides intergovernmental organisations with democratic credibility that can help balance their own legitimacy deficit. In fact, Reimann argues that this (the promotion of NGOs as democratic representatives in global institutions) has turned NGOs into indispensable partners where intergovernmental organisations have come to rely on NGOs 'to fill institutional gaps and help them achieve their stated goals' (Reimann 2006: 64).

Smyth points out that if arguments about NGOs providing legitimacy to global governance processes are valid, 'the implications are far-reaching' because NGOs would have to be factored into new and old institutions alike as legitimate actors (Smyth 2012: 380). Theories that demonstrate the successful integration of NGOs into global structures, and the power they wield therein, have also generated arguments about a need for effective 'democratic control of NGOs ... [with] a distinctive legal character' (Macdonald 2008: 558)—projecting an NGO regulatory regime that is fully integrated into international institutional law and global institutions. Thus, although NGOs have established their de facto powers in global governance certain aspects of their legitimacy are still lacking, especially regarding issues pertaining to their legal character.

In sum, the new institutional model provides insights into the wider role NGOs play. It helps to understand the limits of NGOs' legitimate role as global actors by pointing out that despite NGOs ability to generate normative change, NGOs are limited as embedded entities of intergovernmental institutions, beyond that the legal dimension of their legitimacy is domestic not international, and can in some instances hinder rather than help balance international legitimacy deficits (Reiser and Kelly 2010-2011). The new institutional model provides a framework for normative analysis of NGO legitimacy in the context of global governance. NGOs are theorised as embedded entities in global structures capable of providing a legitimacy function to counter the democratic deficit in intergovernmental institutions where NGOs can act 'as a solvent against the strictures of sovereignty' (Charnovitz 2006: 348). The criticism is that NGO legitimacy is theorised exogenously as it is conferred rather than constituted and passed on as a solution to the legitimacy deficit of the global system, thus ducking the political question of NGOs. The critical model, however, grapples with it by focusing on empowerment. 


\section{The Critical Model}

The critical model departs from the other models on the issue of politics. The premise of the model is that not addressing the political nature of NGOs can distort the analyses of NGOs' legitimacy claims. The theories emphasise the role of NGOs in international development and engage with the legitimacy problems of NGOs in terms of power. It is therefore in stark contrast to the market model as it theorises the role of NGOs as political.

The arguments presented in the critical model pertain to the political dimension of legitimacy and 'how to put effective limits on power' in world politics, whether exercised by public or private actors (Collingwood 2006: 1). It focuses on NGOs as a pathway to empower those who are disadvantaged or excluded from the decision-making processes in society (domestic and international). The critical model is to a large extent a response to the theories that comprise the other models. It embraces the social change model's emphasis on 'bottom-up' agency, but emphasises more strongly its normative dimension in terms of empowerment, the inclusion of culturally diverse societies and groups, and the politics of access and redistribution of resources. Much of the research focuses on the context of NGOs in international development (Bebbington et al. 2008; Walton 2013).

In their seminal work on NGO legitimacy in the 1990s, Edwards and Hulme argued that the legitimacy of NGOs was tied with government funding where too much state funding jeopardised their claim to legitimacy and affected their 'ability to act independently in pursuing their goals' (Edwards and Hulme 1996: 962), therefore making NGOs over-dependent or vulnerable to the agenda of the state. Hulme has advanced this in his recent work by arguing that the depoliticising of NGOs happens as they drift towards global power and away from the powerless: 'Without greater commitment to their community-driven and grassroots approach, there is no means through which NGO programmes can be realigned with local realities and brought closer to goals of empowerment' (Banks and Hulme 2012: 14).

Bebbington has advanced a similar argument in his work on the issue of representation and relations between rural communities and donors (Bebbington 1997, 2005, 2008). He argues that NGOs are not forthcoming about the problems they encounter in the field in fear of financial retribution from donors. In this NGO, legitimacy has become susceptible to donors' needs and requirements thus cloaking the political nature of poverty that NGOs should be addressing. Priority is given to accountability towards donors and securing a long-term income through government contracts where NGOs concentrate on the 'middle poor more than [...] the chronically poor' to create market-orientated solutions to poverty (Bebbington 2005: 946). This, he argues, risks prolonging politically abusive environments and reinforcing injustices that never get resolved at the political level where NGOs' representation of poor people is depoliticised to avoid difficult 'questions of inequality, redistribution, and social organization' (Bebbington 2005: 940-46).

The critical model is more focused on power, and on legitimacy as a justification of power. Rather than imposing a 'fixed definition of legitimacy' based on the liberal democratic doctrine, Collingwood suggests a mediation between sociological and normative aspects of legitimacy '. . . that allows for competing perceptions and visions of what "legitimate" rules and membership of international society actually mean' (Collingwood 2006: 454). In a similar vein, Lister argues that technical definitions of NGOs tend to hide their agency within power structures and power relations implying that 'correct organizational structures and procedures will ensure legitimacy' (Lister 2003: 189). Hence, questions about rightful membership and conduct are not necessarily focused on legality but the normative and social 
aspects of what counts as legitimate. These attempts to open a dialogue about power and legitimacy in world politics also opens the door to NGOs and analysis of their political agency as agents in their own right independent of states and intergovernmental organisations (Charnovitz 2011).

The critical model embraces the political role of NGOs that is seen as an antidote to the over reliance of the other models on the neoliberal agenda. It criticises NGO legitimacy by analysing their access to power, power relationships, and over-compliance with donor agendas at the cost of the poorest. The critical model highlights the capacity that is embedded in NGOs' missions and their potential for introducing a legitimate political voice-in particular, when it comes to addressing injustice, resource redistribution, and power. Yet, the problem remains that although NGO legitimacy is being theorised in contrast to the other models by asking demanding questions about the political nature of power and poverty, it is hard to escape

TABLE 1

NGO Legitimacy characteristics/defining features of the models

\begin{tabular}{|c|c|c|c|c|}
\hline & $\begin{array}{l}\text { Market } \\
\text { model }\end{array}$ & $\begin{array}{c}\text { Social change } \\
\text { model }\end{array}$ & $\begin{array}{c}\text { New institutional } \\
\text { model }\end{array}$ & $\begin{array}{c}\text { Critical } \\
\text { model }\end{array}$ \\
\hline Research & $\begin{array}{l}\text { Weisbrod } \\
\text { (1998), Frumkin } \\
\text { (2002), Brown } \\
(2008)\end{array}$ & $\begin{array}{l}\text { Salamon and Anheier } \\
\text { (1997), Kendall and } \\
\text { Knapp (1996), Hilton } \\
\text { et al. (2010) }\end{array}$ & \begin{tabular}{|l|} 
Powell and \\
DiMaggio (1991), \\
Reimann (2006), \\
Macdonald (2008)
\end{tabular} & $\begin{array}{l}\text { Edwards and } \\
\text { Hulme (1996), } \\
\text { Bebbington } \\
\text { (2005), Lister } \\
\text { (2003) } \\
\end{array}$ \\
\hline $\begin{array}{l}\text { Theoretical } \\
\text { premises }\end{array}$ & $\begin{array}{l}\text { Neoliberal/ } \\
\text { utilitarian }\end{array}$ & $\begin{array}{l}\text { Social capital/change } \\
\text { theories }\end{array}$ & $\begin{array}{l}\text { Organisational } \\
\text { theories/New } \\
\text { institutional } \\
\text { theories }\end{array}$ & $\begin{array}{l}\text { Marxist/critical } \\
\text { theories }\end{array}$ \\
\hline Keywords & $\begin{array}{l}\text { Demand and } \\
\text { supply }\end{array}$ & $\begin{array}{l}\text { Freedom of } \\
\text { association }\end{array}$ & Norms & Empowerment \\
\hline Vocabulary & \begin{tabular}{l|} 
Nonprofits, \\
Voluntary orgz., \\
Charities, \\
Philanthropy \\
\end{tabular} & $\begin{array}{l}\text { Civil society orgz., } \\
\text { Associations }\end{array}$ & $\begin{array}{l}\text { NGOs, (global) } \\
\text { Civil society }\end{array}$ & $\begin{array}{l}\text { NGOs, Southern } \\
\text { NGOs, Northern } \\
\text { NGOs }\end{array}$ \\
\hline $\begin{array}{l}\text { Level of } \\
\text { organisation }\end{array}$ & $\begin{array}{l}\text { Domestic } \\
\text { (international) }\end{array}$ & $\begin{array}{l}\text { Domestic (cross- } \\
\text { country) }\end{array}$ & $\begin{array}{l}\text { International } \\
\text { (country of } \\
\text { registration) }\end{array}$ & $\begin{array}{l}\text { International } \\
\text { (host country) }\end{array}$ \\
\hline Context & $\begin{array}{l}\text { Market } \\
\text { economies }\end{array}$ & $\begin{array}{l}\text { Democracy } \\
\text { (individuals, society) }\end{array}$ & \begin{tabular}{|l} 
Institutions \\
(networks, \\
systems)
\end{tabular} & $\begin{array}{l}\text { Relationships of } \\
\text { power }\end{array}$ \\
\hline Analysis & $\begin{array}{l}\text { Comparative } \\
\text { advantage, } \\
\text { complimentary } \\
\text { functions to } \\
\text { state }\end{array}$ & $\begin{array}{l}\text { Constitutive } \\
\text { democracy, internal } \\
\text { factors, socialisation, } \\
\text { 'bottom-up' analysis, } \\
\text { social entrepreneurs }\end{array}$ & \begin{tabular}{|l|} 
Organisational \\
environment, \\
promotion of \\
norms in \\
institutions, \\
global \\
governance, norm \\
entrepreneurs \\
\end{tabular} & $\begin{array}{l}\text { Power relations, } \\
\text { donors and } \\
\text { beneficiaries, aid } \\
\text { chains }\end{array}$ \\
\hline Legitimacy criteria & $\begin{array}{l}\text { Performance, } \\
\text { Supply-demand, } \\
\text { Accountability }\end{array}$ & $\begin{array}{l}\text { Representativeness, } \\
\text { Accountability, } \\
\text { Global public } \\
\text { opinion, }\end{array}$ & \begin{tabular}{|l|} 
Institutional \\
processes, NGOs \\
as legitimacy gap \\
fillers in IGOs, \\
Norms
\end{tabular} & $\begin{array}{l}\text { Political } \\
\text { legitimacy, } \\
\text { Representation, } \\
\text { Empowerment }\end{array}$ \\
\hline
\end{tabular}

(Continued) 
TABLE 1

(Continued)

\begin{tabular}{|c|c|c|c|c|}
\hline & $\begin{array}{c}\text { Market } \\
\text { model }\end{array}$ & $\begin{array}{c}\text { Social change } \\
\text { model }\end{array}$ & $\begin{array}{c}\text { New institutional } \\
\text { model }\end{array}$ & $\begin{array}{l}\text { Critical } \\
\text { model }\end{array}$ \\
\hline $\begin{array}{l}\text { Legitimacy } \\
\text { Justifications }\end{array}$ & $\begin{array}{l}\text { NGOs provide } \\
\text { alternative or } \\
\text { complimentary } \\
\text { welfare services }\end{array}$ & $\begin{array}{l}\text { NGOs are } \\
\text { intrinsically good for } \\
\text { democracy }\end{array}$ & $\begin{array}{l}\text { NGOs are } \\
\text { institutionally } \\
\text { embedded in } \\
\text { global } \\
\text { organisations }\end{array}$ & $\begin{array}{l}\text { NGOs are self- } \\
\text { serving } \\
\text { organisationally } \\
\text { and enmeshed in } \\
\text { donors' agendas }\end{array}$ \\
\hline Legitimacy Claims & $\begin{array}{l}\text { Claims are } \\
\text { rooted in } \\
\text { contractual } \\
\text { credibility } \\
\text { (financial, peers) }\end{array}$ & $\begin{array}{l}\text { Claims are social } \\
\text { driven rather than } \\
\text { market driven }\end{array}$ & $\begin{array}{l}\text { Claims are norm } \\
\text { driven and } \\
\text { embedded in } \\
\text { structures }\end{array}$ & $\begin{array}{l}\text { Claims have a } \\
\text { political } \\
\text { dimension and } \\
\text { need political } \\
\text { analysis }\end{array}$ \\
\hline Regulation & Self-regulation & $\begin{array}{l}\text { Self-regulation (or no } \\
\text { regulation) }\end{array}$ & $\begin{array}{l}\text { Derived or } \\
\text { embedded } \\
\text { regulation }\end{array}$ & $\begin{array}{l}\text { Pro-regulation } \\
\text { Democratic } \\
\text { regulation }\end{array}$ \\
\hline Legitimate Role & $\begin{array}{l}\text { Functional- } \\
\text { Apolitical }\end{array}$ & $\begin{array}{l}\text { Democratic-Semi- } \\
\text { political }\end{array}$ & $\begin{array}{l}\text { Complimentary- } \\
\text { Semi-political }\end{array}$ & Political-Political \\
\hline
\end{tabular}

the principles of liberal democracy in international structures especially since many NGOs have internalised them in their own organisation of power to justify their legitimacy claims.

\section{Critical Assessment}

The NGO legitimacy models point to criteria and characteristics-market economies, freedom of association, normative change, and empowerment-that affect how NGO legitimacy is theorised and understood. Each approach has its merits and problems.

The problem with the market model is that the analytical emphasis on accountability leaves the political question untheorised. Accountability regimes, furthermore, seem to put a wedge between the financial aspect and the political aspect of NGO legitimacy raising concerns about donors' agendas and a gap between NGOs and their beneficiaries. Substantiating NGO legitimacy with self-regulation, as suggested by Brown (2008), is encouraged by the governing elites at all political levels, whether domestic, regional, or global. However, self-regulatory regimes instituted by NGOs seem to focus heavily on donors and those in power rather than holding NGOs as powerful actors accountable to their beneficiaries. Self-regulation remains an incomplete justification for NGO legitimacy because it cannot replace democratic control. A common feature in the market model analysis is the preoccupation with individual legitimacy components rather than legitimacy itself, such as accountability criteria and market efficiency. Although these are valuable constructs in legitimacy debates, they can also eclipse the political and democratic dimensions of NGO legitimacy by aligning the debate with the functional/practical concerns of governmental institutions or donors, and thus shifting the focus away from NGOs' role as democratic actors.

Criticisms raised about the social change model highlight the darker shades of civil society and the possible dangers of subcontracting welfare functions (or policy formations) to NGOs because: 'Devolving responsibilities also empowers associations-and this may not be a good thing when associational ties are linked to inequalities in control over economic resources, knowledge, professional skills, and the like' (Warren 2001: 88). Furthermore, reliance on informal 
procedures or loose organisational structures to avoid hierarchy and maintain 'genuine grassroots relations' (sometimes cited as an advantage for NGOs) can pose a risk to NGO legitimacy because 'informal structures easily conceal covert divisions of power and control within organizations, and this danger probably increases with their size' (Atack 1999: 859).

Idealising civil society runs the risk of ignoring the nature of power. Novak warns against such complacency because it can cause researchers to 'exaggerate its [civil society] separateness from state power and other forms of social, economic, and political organization' and overlook 'the public coercive powers that underlie much supposedly private voluntary activity' (Novak 2001: 163). Skocpol posits a similar criticism, when she argues that the changing associational practices in NGOs have led them to become 'much more focused on specialised, instrumental activities than on broad expressions of community or fellow citizenship' (Skocpol 2003: 62-3). Whereas the social change model emphasises the autonomy of the third sector and the democratic nature of NGOs, the new institutional model focuses on NGO legitimacy in an institutional context using normative analysis. The representative problem of NGOs at the international level has resonated with many governments that do not share the liberal democratic politics of the West, many of whom like to dismiss NGOs as unsuitable actors in political forums and repeatedly attempt to block the input of NGOs, whether domestically or in international forums.

However, even if an NGO's declared mission is apolitical and even if NGOs were 'only' delivering services, they are still susceptible to politics, especially as institutionally embedded entities of intergovernmental organisations, where they are often perceived as representatives of global publics. This begs the following question: is it possible to analyse NGO legitimacy as apolitical? If NGOs seek to change the lives of others-whether by delivering welfare services or by campaigning to highlight unpopular political problems where politicians are not delivering or caring, or worse, systematically ignoring the plight of certain groups in society-by changing the behaviour of those whose duty it is to deliver and care, is it possible for them to claim legitimacy as apolitical agents without falling prey to the system they seek to change? The theories in the critical model raise awareness about politics NGOs face in their work and the conflict this can cause with the aid regime NGOs are part of as receivers of development funds. The question raised in the critical model is whose agenda are NGOs prioritising? Is it their beneficiaries' or NGOs' own organisational survival, that is, by avoiding reporting politically toxic problems that might cost them funds?

\section{Conclusion}

To sum up, the arguments presented in the market model might be used in a discussion on NGOs in the context of philanthro-capitalism and foundations where NGOs are seen to be operating in a market place, albeit with a different pretext than businesses. This is mainly an apolitical role that focuses mostly on fund-raising, financial accountability, and performance indicators. The arguments presented in the social change model might talk about NGOs as social entrepreneurs, with an ability to socialise members and the local community. This raises political questions about NGOs' democratic role and constituents and whom they are representing as grassroots organisations (members, donors, ideas) - and how their representative abilities at the domestic level can be transposed onto the international level. The arguments presented in the new institutional model focus on structures and norms and how NGOs influence the international system. NGOs are seen to compensate for the legitimacy 
shortcomings in global governance acting as catalysts between these institutions and the public. The arguments introduced in the critical model involve a criticism of the power imbalance between the wealthy and the poor where the latter's political interests are marginalised. NGO legitimacy is theorised as a political force empowering those who are excluded or marginalised in political processes. In this, it presses for a more open approach to the question of NGOs' political agency.

The legitimacy criteria generated by the models vary. Whilst the market model produces criteria to clarify the operational capacity of NGOs, the social change model produces criteria to evaluate the representativeness of NGOs as internally generated (and often measured in a domestic context). The new institutionalism model produces normative criteria to assess NGO legitimacy in the context of intergovernmental institutions and global governance, although these can also apply domestically. The social change and new institutional models raise difficult questions about NGOs, their representativeness and democratic role in world politics. The critical model tries to answer this by pointing out that NGO legitimacy strategies differ and even though NGOs claim to represent the poor donors' demands can still silence the political voice of NGOs and thus the concerns of their beneficiaries.

The emphasis on roles opens up questions about NGOs' constituents. What the models highlight is that there are different audiences for NGO legitimacy claims, whether they are raised in the capacity of representation, norms, or solidarity. This shifts the focus onto the democratic relationship NGOs have with their various constituents that are expected to accept, grant, confer, or support their legitimacy claims. Thus, there is a great need to clarify the 'democratic' component of NGOs in the context of their relationship with their constituents. We need to be able to justify the legitimacy of the roles NGOs play in world politics, in particular if NGOs' participation is to shape the debate about democracy at the international level and claim legal validity. This paper has outlined a framework for identifying the key arguments currently used in the literature to analyse NGO legitimacy. This hopefully helps clarifying how different theoretical approaches generate different analysis of the role NGOs play in international relations, a role that moves from apolitical, to semi-political, to political.

\section{ACKNOWLEDGEMENTS}

Earlier versions of this article were presented at the annual conference of the Development Studies Association in 2012, and at a Seminar at Durham University in 2014. The author hereby thanks those who have reviewed this article for their helpful comments.

\section{References}

ANHEIER, H. and H. KATZ. 2004. Network approaches to global civil society. In Global Civil Society 2004/5, edited by H. Anheier, Marlies Glasius and Mary Kaldor. London: Sage, pp. 206-21.

ATACK, I. 1999. Four criteria of development NGO legitimacy. World Development 27 (5): 855-64. BANKS, N. and D. HULME. 2012. The role of NGOs and civil society in development and poverty reduction. BWPI Working Paper. Available at http://www.bwpi.manchester.ac.uk/ medialibrary/publications/working_papers/bwpi-wp-17112.pdf, accessed 4 January 2015.

BEBBINGTON, A. 1997. New states, new Ngos? Crises and transitions among rural development NGOs in the Andean region. World Development 25 (11): 1755-65. 
BEBBINGTON, A. 2005. Donor-NGO relations and representations of livelihood in nongovernmental aid chains. World Development 33 (6): 937-50.

BEBBINGTON, A. 2008. Social dimensions of rural resource sustainability. (School of Environment and Development, University of Manchester). Available at http://www.sed.manchester.ac.uk/ research/andes/publications/conferences/social_dimensions.pdf, accessed 7 April 2010.

BEBbington, A., S. HICKEY and D.C. MITLIN (eds). 2008. Can NGOs Make a Difference? The Challenge of Development Alternatives. London: Zed Books.

Beetham, D. 1991 [2013]. The Legitimation of Power. Basingstoke: Palgrave Macmillan.

BERNSTEIN, S. 2011. Legitimacy in intergovernmental and non-state global governance. Review of International Political Economy 18 (1): 17-51.

BEXELL, M. 2014. Global governance, legitimacy and (De)legitimation. Globalizations 11 (3): 289-99.

BODANSKY, D. 1999. Legitimacy of international governance: a coming challenge for international environmental law. American Journal of International Law 93 (3): 596-624.

BROWN, L.D. 2008. Creating Credibility: Legitimacy and Accountability for Transnational Civil Society. Sterling: Kumarian Press.

BUCHANAN, A. and R.O. KEOHANE. 2006. The legitimacy of global governance institutions. Ethics \& International Affairs 20 (4): 405-37.

CASHORE, B. 2002. Legitimacy and the privatization of environmental governance: how non-state market-driven (NSMD) governance systems gain rule-making authority. Governance: An International Journal of Policy, Administration and Institutions 15 (4): 503-29.

CHARNOVITZ, S. 2006. Nongovernmental organizations and international law. The American Journal of International Law 100 (2): 348-72.

CHARNOVITZ, S. 2011. The illegitimacy of preventing NGO participation. Brooklyn Journal of International Law 36 (3): $891-910$.

CLARK, A.M. 2001. Diplomacy of Conscience: Amnesty International and Changing Human Rights Norms. Oxford: Princeton University Press.

CLARK, I. 2007a [2005]. Legitimacy in International Society. Oxford: Oxford University Press.

CLARK, I. 2007b. Setting the revisionist agenda for international legitimacy. International Politics 44: 325-35.

CLEMENS. 2006. The constitution of citizens: political theories of nonprofit organizations. In The Nonprofit Sector: A Research Handbook, edited by W.W. Powell and R. Steinberg. 2nd edn. London: Yale University Press, pp. 207-20.

COLLINGWOOD, v. 2006. Non-governmental organisations, power and legitimacy in international society. Review of International Studies 32 (03): 439-54.

COUNCIL OF EUROPE (COMMITTEE OF MINISTERS). 2007. Recommendation CM/Rec (2007)14 of the Committee of Ministers to Member States on the Legal Status of Non-Governmental Organisations in Europe. Strasbourg: Council of Europe.

CRACK, A. 2013. INGO accountability deficits: the imperatives for further reform. Globalizations 10 (2): 293-308.

EBRAHIM, A. 2009. Placing the normative logics of accountability in "Thick" perspective. American Behavioral Scientist 52 (6): 885-904.

EDWARDS, M. and D. HULME. 1996. Too close for comfort? The impact of official aid on nongovernmental organisations. World Development 24 (6): 961-73.

ERIKSEN, S.S. and O.J. SENDING 2013. There is no global public: the idea of the public and the legitimation of governance. International Theory 5 (02): 213-37. 
FINNEMORE, M. and K. SIKKINK. 1998. International norm dynamics and political change. International Organization 52 (04): 887-917.

FRUMKIN, P. 2002. On Being Nonprofit: A Conceptual Policy Primer. Cambridge, MA: Harvard University Press.

GIDRON, B., R.M. KRAMER and L.M. SALAMON (eds). 1992. Government and the Third Sector: Emerging Relationships in Welfare States. San Francisco: Jossey-Bass Publishers.

GLOBAL REPORTING INITIATIVE. 2011. Sustainability reporting guidelines: NGO sector supplement. Available at https://www.globalreporting.org/resourcelibrary/NGOSS-Complete.pdf, accessed 4 January 2015.

GÖTZ, N. 2008. Reframing NGOs: the identity of an international relations non-starter. European Journal of International Relations 14 (2): 231-58.

HALPIN, D. 2009. NGOs and democratisation: assessing variation in the internal democratic practices of NGOs. In NGOs in Contemporary Britain: Non-State Actors in Society and Politics Since 1945, edited by N. Crowson, M. Hilton and J. Mckay. Basingstoke: Palgrave Macmillan, pp. 261-80. HALPIN, D. and P. MCLAVERTY. 2010. Legitimating INGO advocacy: the case of internal democracies. In Evaluating Transnational NGOs: Legitimacy, Accountability, Representation, edited by J. Steffek and K. Hahn. Basingstoke: Palgrave Macmillan, pp. 55-73.

HILTON, M., J. MCKAY, N. CROWSON and J.-F. MOUHOT. 2010. Civic participation and social responsibility. Briefing Paper to the Strategy Unit of the Cabinet Office. Birmingham: University of Birmingham. Available at http://www.ngo.bham.ac.uk/Civic\%20Participation.pdf, accessed 18 November 2011.

HONE, M.C. 1989. Aristotle and Lyndon Baines Johnson: thirteen ways of looking at blackbirds and nonprofit corporations-the American Bar association's revised model nonprofit corporation act. (Symposium: what is charity? Implications for law and policy). Case Western Reserve Law Review 39 (3): 751-63.

INGO ACCOUNTABILITY CHARTER. 2005. The Commitment of INGOs to Accountability. Berlin: INGO Accountability Charter. Available at http://www.ingoaccountabilitycharter.org/, accessed 16 September 2011

INGO ACCOUNTABILITY CHARTER. 2014. The accountability charter: 10 commitments to accountability by international non-governmental organisations. Available at http://www.ingoaccountabi litycharter.org, accessed 11 October 2014.

JEATER, D. 2011. Zimbabwe: International NGOs and aid agencies_Parasites of the poor? Rethinking Zimbabwe. Harare: African Arguments. Available at http://africanarguments.org/2011/08/08/ parasites-of-the-poor-international-ngos-and-aid-agencies-in-zimbabwe-by-diana-jeater, accessed 4 January 2015.

JORDAN, L. and P.V. TUIJL. 2006. Rights and responsibilities in the political landscape of NGO accountability: Introduction and overview. In NGO Accountability: Politics, Principles and Innovations, edited by L. Jordan and P.V. Tuijl. London: Earthscan, pp. 3-20.

KAMmINGA, M.T. 2007. What makes an NGO 'Legitimate' in the eyes of states? In NGO Involvement in International Governance and Policy: Sources of Legitimacy, edited by A. Vedder. Leiden: Martin Nijhoff Publishers, pp. 175-95.

KECK, M.E. and K. SIKKINK. 1999. Transnational advocacy networks in international and regional politics. International Social Science Journal 51 (159): 89-101.

KENDALL, J. and M. KNAPP. 1996. The Voluntary Sector in the United Kingdom. Manchester: Manchester University Press.

KISSLING, C. 2008. The evolution of CSOs' legal status in international governance and its relevance for the legitimacy of international organizations. In Civil Society Participation in European and 
Global Governance: A Cure for the Democratic Deficit? edited by J. Steffek, C. Kissling and P. Nanz. Basingstoke: Palgrave Macmillan, pp. 30-52.

LANG, S. 2012. NGOs, Civil Society, and the Public Sphere. Cambridge: Cambridge University Press.

LISTER, S. 2003. NGO legitimacy: technical issue or social construct? Critique of Anthropology 23 (2): $175-92$.

MACDONALD, T. 2008. What's so special about states? Liberal legitimacy in a globalising world. Political Studies 56 (3): 544-65.

MARAGIA, B. 2002. Almost there: another way of conceptualizing and explaining NGOs' quest for legitimacy in global politics. Non-State Actors and International Law 2: 301-32.

MATHEWS, J.T. 1997. Power shift. Foreign Affairs 76 (1): 50-67.

NOVAK, W.J. 2001. The American law of association: the legal-political construction of civil society. Studies in American Political Development 15 (Fall 2001): 163-88.

O'NEILL, J. 2001. Representing people, representing nature, representing the world. Environment \& Planning C: Government and Policy 19: 483-500.

PATTBERG, P. 2005. The institutionalization of private governance: how business and nonprofit organizations agree on transnational rules. Governance-an International Journal of Policy and Administration 18 (4): 589-610.

PERUZZOTTI, E. 2006. Civil society, representation and accountability: restarting current debates on the representativeness and accountability of civic associations. In NGO Accountability: Politics, Principles and Innovations, edited by J. Lisa and P.V. Tuijl. London: Earthscan, pp. 43-58.

PHILLS, J.A.J. 2005. Integrating Mission and Strategy for Nonprofit Organizations. New York: Oxford University Press.

POWELL, W.W. and P.J. DIMAGGIO (eds). 1991. The New Institutionalism in Organizational Analysis. London: The University of Chicago Press.

PUTNAM, R.D. 2000. Bowling Alone: The Collapse and Revival of American Community. London: Simon \& Schuster.

REIMANN, K.D. 2006. A view from the top: international politics, norms and the worldwide growth of NGOs. International Studies Quarterly 50 (1): 45-68.

REISER, D.B. and C.R. KELLY. 2010-2011. Linking NGO accountability and the legitimacy of global governance. Brooklyn Journal of International Law 36 (3): 1011-73.

SALAmON, L.M. and H.K. ANHeIER. 1997. Defining the Nonprofit Sector: A Cross-National Analysis. Manchester: Manchester University Press.

SCHOLTE, J.A. 2007. Civil society and the legitimation of global governance. Journal of Civil Society 3 (3): 305-26.

SHORT, C. 1999. NGOs in a Global Future. Birmingham: Birmingham University. Available at http://www. clareshort.co.uk/speeches/DFID/13\%20Jan\%201999.pdf, accessed 2 January 2015.

SKoCPoL, T. 2003. Diminished Democracy: From Membership to Management in American Civic Life. Norman: University of Oklahoma Press.

SLIM, H. 2002. By what authority? The legitimacy and accountability of non-governmental organisations. International Meeting on Global Trends and Human Rights. September 2001: Impacts on Human Rights Work. Geneva: The International Council on Human Rights Policy . SMYTH, S. 2012. NGOs and legitimacy in international development. University of Kansas Law Review 61 (2): $377-440$.

STEFFEK, J. and K. HAHN (eds). 2010. Evaluating Transnational NGOs: Legitimacy, Accountability, Representation. Basingstoke: Palgrave Macmillan. 
UnItEd nations. 2004. We the Peoples: Civil Society, the United Nations and Global Governance: Report of the Panel of Eminent Persons on United Nations-Civil Society Relations [Cardoso Report]. New York: United Nations.

VAKIL, A. 1997. Confronting the classification problem: toward a Taxonomy of NGOs. World Development 25 (12), 2057-70.

WALTON, O. 2013. 'Everything is politics': understanding the political dimensions of NGO legitimacy in conflict-affected regions. In Charities in the Non-Western World, edited by R.A. Brown and J. Pierce. Abingdon: Routledge, pp. 19-39.

WAPNER, P. 1996. Environmental Activism and World Civic Politics. New York: State University of New York Press.

WARREN, M.E. 2001. Democracy and Association. Oxford: Princeton University Press.

WEISBROD, B.A. (ed). 1998. To Profit or Not to Profit: The Commercial Transformation of the Nonprofit Sector. Cambridge: Cambridge University Press.

WILLETTS, P. 2006. The Cardoso report on the UN and civil Society: functionalism, global Corporatism, or global democracy? Global Governance 12 (3): 305-24.

WILLETTS, P. 2011. Non-Governmental Organisations in World Politics: The Construction of Global Governance. Abingdon: Routledge.

Erla Thrandardottir is a visiting research fellow at City University London. Her research focuses on legitimacy and NGOs, in particular the link between legality and legitimacy. Her PhD thesis explored the internal legitimacy of three large NGOs (Amnesty, Cafod, Greenpeace) in the United Kingdom and the power relations these units have with the international offices of their global networks. Erla is currently working on how NGOs claim legal legitimacy at the international level and how this affects our understandings of their role as democratic agents in global politics. She is currently writing a chapter on knowledge production in Greenpeace in an edited book and collaborating on a paper about Greenpeace in India. Email: erla.thrandardottir.1@city.ac.uk 